\title{
Communication Strategies and Foreign Language Speech Production
}

\author{
Gicele Vergine Vieira Prebianca \\ Universidade Federal de Santa Catarina - UFSC \\ Mailce Borges Mota Fortkamp \\ Universidade Federal de Santa Catarina - UFSC
}

RESUMO: Este estudo investiga a relação entre o uso de estratégias de comunicação e o desempenho oral em uma língua estrangeira (L2). Trinta participantes foram alocados em grupos de nível pré-intermediário, intermediário e avançado. A fluência oral dos participantes foi determinada por meio da velocidade de fala (LENNON, 1990). Três narrativas foram usadas para eliciar a produção oral em L2, em três sessões diferentes. A análise revelou que a relação entre estratégias de comunicação e fluência oral em L2, medida pela velocidade da fala, não é estatisticamente significante em nenhum dos níveis de proficiência. Finalmente, a análise revelou que a variável velocidade da fala parece não ser suficiente para examinar a relação entre o uso de estratégias de comunicação e o desenvolvimento da produção oral em L2. Para explicar os poucos exemplos de correlações estatisticamente significantes entre a velocidade da fala e tipos de estratégias de comunicação, é sugerido que, devido aos inúmeros fatores que afetam a fluência em L2, outros aspectos de produção da fala sejam levados em consideração. Além disso, a natureza das tarefas propostas e a demanda cognitiva que essas tarefas exerceram podem ter contribuído para a aparentemente limitada melhora da produção oral dos participantes ao longo das sessões.

PALAVRAS-CHAVE: estratégias de comunicação, fluência oral, produção oral em L2.

\begin{abstract}
This study investigated the relationship between communication strategies use and foreign language (L2) oral production. Thirty participants were assigned to a pre-intermediate, an intermediate or an advanced group. Their oral fluency was assessed by means of speech rate (LENNON, 1990). L2 speech production was elicited by means of three narrative tasks in three different sessions. Data analysis revealed that the relationship between communication strategies use and L2 oral fluency, as measured by speech rate, is not statistically significant in any of the three proficiency levels. The analysis also revealed that speech rate, alone, is not enough to examine the relationship between communication strategies use and L2 speech production. To explain the few instances of significant statistical correlations between speech rate and types of communication strategies, it is suggested that due to the multitude of factors affecting L2 oral fluency, other aspects
\end{abstract}




\begin{abstract}
of speech production need to be taken into consideration. In addition, the nature of tasks and their cognitive demands might have contributed to learners' apparently limited oral improvement across sessions.

KEY-WORDS: communication strategies, oral fluency, L2 oral production.
\end{abstract}

\title{
Introduction
}

Research on communication strategies (CS) has been developed mainly in terms of the identification and classification of these strategies (VARADI, 1983; TARONE, 1980; FAERCH; KASPER, 1983; POULISSE, 1993; DÖRNYEI; KORMOS, 1998); the influence of task type and proficiency related factors on CS choice (POULISSE; SCHILS, 1989; CHEN, 1990; PARIBAKHT, 1985; YARMOHAMMADI; SEIF, 1992); the use of CS in formal and informal environments (RODRIGUES, 1999); and the use of process versus product-oriented CS (FAERCH; KASPER, 1983; BIALYSTOK, 1983; BIALYSTOK, 1990).

Given that the existing research on L2 speech production has not systematically studied the relationship between oral performance and strategic language use and that L2 learners make use of CS in order to achieve communicative goals through the most efficient and optimal way (KASPER; KELLERMAN, 1997), it seems reasonable to suggest that performance in speech production may be related to CS use. Therefore, the objective of the present study is to investigate the relationship between CS use and L2 speech production in different stages of L2 proficiency. The results of the present study might shed light on the processes involved both in the performance of L2 speaking tasks and in the development of the skill.

This paper is organized into six major sections. Right after this introductory section, a review of the literature on speech production and CS is presented. The third section presents the method adopted in the present study. The results are reported in section 4 and discussed in section 5. Finally, section 6 brings the conclusions and makes suggestions for future research.

\section{Review of Literature}

\section{Speech Production Models}

Over the last decades, psycholinguistic research has devoted much attention to oral production. The most influential model of speaking is the 
one proposed by Levelt (1989), which was originally developed to explain oral production in first language.

In his model, Levelt proposes that the construction of a verbal message involves conceptual and linguistic processes. Through macro and micro planning, speakers plan the content of the message and their communicative goals (conceptual information) and decide on the most appropriate type of speech to convey their intentions to their interlocutors. All the processes involving message generation take place in one of the four components responsible for processing speech - the conceptualizer - and the final product of this phase is called the preverbal message. The preverbal message generated in the conceptualizer serves as input for the next processing component - the formulator. In this phase, speakers formulate the grammatical and phonological structure of the message. The final product of the processes that take place in the formulator is a phonetic plan (LEVELT, 1989), which is then sent to the next component in the model, the articulator. The function of the articulator is to transform the phonetic plan into overt speech, by controlling the articulatory muscles responsible for the execution of the speech sounds. Levelt's model also proposes a speech-comprehension system, by means of which speakers can monitor and correct disfluencies in their speech during and after articulation.

Most accounts of L2 speech production are based on Levelt's model, with some adaptations. For instance, Poulisse and Bongaerts (1994) propose that L1 and L2 lexical items are stored in a single network and labeled with a language tag specifying to which language they belong. This is necessary because, according to Poulisse (1997), L1 lexical items may share some conceptual characteristics with L2 items and, thus, might be activated during L2 speech production.

In his account of L2 speech production, De Bot (1992) hypothesizes that before actually starting to encode the message, the speaker needs to decide which language to use. This decision is taken in the conceptualizer. In this case, the preverbal message would contain language specifications that would lead them to the correct, language-specific formulator. As remarked by Poulisse (1997), in De Bot's model, L1 and L2 lexical items share the same conceptual network, but are stored in different subsets. In order to account for language switches during speech production, De Bot (1992) suggests that two speech plans are simultaneously carried out by the L2 speaker - one for the language that is being used and another for 
the language that is not being used at the moment. De Bot (1992) assumes that the articulator is language-independent and contains syllable programs and pitch patterns for all languages.

\section{Empirical studies on Communication Strategies (CS)}

Studies on CS have concentrated on the influence of task types and proficiency levels on CS use (POULISSE; SCHILS, 1989, CHEN, 1990, PARIBAKHT, 1985, YARMOHAMMADI; SEIF, 1992), on the use of CS in real classrooms (FLYMAN, 1997, RODRIGUES, 1999), and on strategy training (MANCHÓN, 2000).

Aiming at investigating the similarities between L1 and L2 referential behavior (speakers' ability to refer to concrete and abstract concepts), Bongaerts and Poulisse (1989) report on a study carried out as part of the Nijmegen project on the use of compensatory (or referential ${ }^{1}$ ) strategies. The authors examined the speech of 30 secondary school pupils and 15 university students of English as an L2, divided into 3 groups of 15 speakers. Participants were asked to describe 12 abstract shapes to a native speaker, so that he/she could arrange the pictures in the same order in which they were described. The task was carried out three times - twice in Dutch (learners' L1) and one in English. Results suggest that when L1 and L2 speakers are faced with the same referential problems, they tend to solve them similarly, by adopting holistic analogical strategies, that is, relating the abstract shape with some other real-word object.

The barriers L2 speakers may encounter during the course of communication and the way they choose to deal with these difficulties appear to influence their final oral production as well as their communicative competence. Paribakht (1985) investigated the relationship between Persian ESL learners' level of proficiency and their use of CS. Twenty adult Persian learners of English took part in the experiment. Participants were required to convey twenty lexical items to a native interlocutor. The items consisted of ten abstract and ten concrete nouns, which should be communicated without being explicitly mentioned. Data analysis resulted in a framework of language proficiency, comprising four main approaches related to the

\footnotetext{
${ }^{1}$ Referential strategies are those used by speakers to describe the relationship between words and things, concepts and objects and what they stand for (RICHARD, PLATT; PLATT, 1992).
} 
source of knowledge learners employed in their CS use: (1) the linguistic approach; (2) the contextual approach; (3) the conceptual approach; and (4) the mime approach. Subjects' purpose for using each approach was then considered in order to identify the specific CS which constituted each approach. The results indicated that high-proficiency speakers were able to employ CS from the linguistic approach more frequently, since they had a better and richer linguistic knowledge of language at their disposal. As far as the concept of communicative competence is concerned, Paribakht states that as L2 speakers become more mature and aware of the linguistic system they are learning, their strategic competence varies according to their proficiency level.

In a similar study, Chen (1990) shows that speakers' communicative competence can be developed by building up learners' strategic competence. According to Chen, strategic competence refers to learners' improvement of their ability to engage in communicative situations and deal with their inadequacies by means of communication strategies. In his study, Chen investigated the influence of learners' proficiency level on the speakers' choice of CS. Two groups of six Chinese EFL learners, divided according to their level of proficiency, participated in the study. Learners were asked to perform a concept-identification task, in which they had to communicate two concrete and two abstract concepts, from a list of 24 , to a native speaker without using the exact word. The native speaker was asked to identify the concept and rank the effectiveness of the CS used to convey each concept, on a scale from 1 (not effective) to 5 (effective). In order to analyze the data, Chen developed a taxonomy for CS based partially on previous research and partially on the new data. This taxonomy was defined taking into account the kind of information learners drew upon to overcome their communicative difficulties, thus, yielding five categories: (1) Linguisticbased CS, (2) Knowledge-based CS, (3) Repetition CS, (4) Paralinguistic CS, and (5) Avoidance CS. The analyses suggested that, despite the fact that low-proficiency learners were able to use more CS, the higher-proficiency ones used CS in a more efficient fashion. The more proficient speakers relied on CS based on their knowledge of the language, being thus able to communicate their messages in a more straightforward fashion.

An experiment conducted by Yarmohammadi and Seif (1992) aimed at analyzing learners' choice of CS in relation to the kind of task they were expected to perform. The study was carried out with fifty-one intermediate students of English. Learners were asked to perform different tasks which 
involved picture descriptions and retelling of stories in English and Persian via written and oral language production. Results showed that certain CS, such as translation and code-switching strategies, varied according to the kind of task performed by learners. However, the authors claimed that in general the frequency and proportion of the use of achievement strategies remained almost the same throughout different task types. The authors state that learners do not select CS randomly; rather, they seem to adopt a systematic procedure to employ the CS that seem more appropriate to fill the gaps they encounter during communication.

The effects of task and proficiency on L2 learners' use of compensatory strategies (CpS) have also been examined by Poulisse and Schils (1989). In Poulisse and Schils' (1989) study, CpS were considered to be achievement strategies employed by L2 learners in order to reach their communicative goal. Forty-five Dutch participants divided into three groups of 15 advanced, intermediate and beginning students, participated in the study. Learners were asked to perform three different tasks - (i) a picture description task, (ii) a story-retelling task heard in Dutch and told in English, and (iii) a 20-minute interview with a native speaker of English. As pointed out by the authors, learners' proficiency level had a limited effect on CpS choice. However, when this variable played a role, it was inversely related to the number of strategies used. Thus, advanced L2 learners employed fewer CpS than the less proficient ones. Poulisse and Schils (1989) suggest that less proficient learners need to resort to CS more often due to their limited command of the language. Regarding task-related influence, results showed that L2 learners are sensitive to the features of the task itself, such as task demands, context, time constraints and the presence of an interlocutor, therefore adopting $\mathrm{CpS}$ that are more informative and can reach the requirements of the communicative task being performed.

Results indicating task-type influence on CS use have also emerged from Rodrigues' (1999) study, which investigated L2 speakers of German communicating in a formal environment in Brazil. The study aimed at analyzing the relationship between the classroom context and learners' use of CS as well as the extent to which interaction among learners and the teacher might influence CS use. Findings suggested that cooperative and non-linguistic strategies such as mime were frequently used during classroom interaction, thus showing that the classroom context seems to influence CS use. One important finding of Rodrigues' work is that learners' strategic behavior seems to be sensitive to environmental features, which may affect 
their oral performance in different ways. In addition, Rodrigues highlights the potential teaching effect of CS on the development of the oral ability. As pointed out by the author, CS governed by achievement behavior may lead learners to expand their resources, thus improving their L2 oral competence.

One important aspect of the study of CS in the L2 area is the choice of a taxonomy. In the present study we have opted for the taxonomy proposed by Dörnyei and Kormos (1998). Dörnyei and Kormos (1998) relate the CS presented in their taxonomy with the stages of oral production defined by Levelt (1989) in his monolingual model of speech processing and its L2 versions (mainly DE BOT, 1992, and POULISSE; BONGAERTS, 1994). According to the authors, there are four sources of problems in L2 communication, (1) L2 resource deficits, (2) processing time pressure, (3) perceived deficiencies in the speaker's own performance, and (4) perceived deficiencies in the interlocutor's performance.

Resource deficits in L2, as proposed by Dörnyei and Kormos (1998), are related to deficient grammatical and phonological competence and the lack of L2 lexical knowledge. While coping with problems in retrieving words in a second language in order to convey an intended message, speakers may undergo two different processes. The first process would involve abandoning or changing the original speech plan, and the second would keep the macro-plan (that is, speakers' communicative goals) and modify the preverbal message (the form of the message). Regarding the first option, speakers may leave the message incomplete (message abandonment), avoid certain L2 structures (message reduction), or replace the original message due to the lack of linguistic resources (message replacement).

When deciding to reformulate the preverbal message, speakers may apply compensatory strategies to compensate for their lexical deficit, such as substitution strategies, substitution plus strategy and reconceptualization strategies. Concerning grammatical deficits, L2 speakers may apply problemsolving mechanisms that change some features of the lexical item either in terms of form or structure, by means of overgeneralization (the use of L2 rules to create a non existing L2 word) or transfer (the use of L1 rules to construct a non existing L2 lexical item). Another option available to speakers is the strategy of grammatical reduction, which involves the use of simplified grammatical structures. In this case, the meaning of the message is guessed by the interlocutor, by means of contextual clues. L2 speakers may also 
experience problems related to phonological and articulatory encoding and resort to strategies of phonological retrieval.

The problem-solving mechanisms concerning time pressure are related to delays in the production of $\mathrm{L} 2$ speech, since retrieval in a second language requires more time processing than in L1 (DÖRNYEI; KORMOS, 1998). As pointed out by these authors, speakers resort to three possible strategies when they notice speech processing may take longer. First, speakers may give up the message by avoiding problems in communication. Second, they might be able to alternate encoding mechanisms, and third, speakers may apply stalling mechanisms - the use of pauses and repetitions, which allow them to gain time to plan the next stretch of speech.

When communication deficits are related to deficiencies in the speaker's own language output, Dörnyei and Kormos refer to a problemsolving mechanism named self-correction or self-repair. Self-corrections or repairs can be of four different kinds: (1) error repair - correcting "accidental lapses in one's own speech"; (2) appropriacy repair - "correcting inappropriate or inadequate information in one's own speech"; (3) different repair - "changing the original speech plan by encoding different information", and (4) rephrasing repair - "repeating the slightly modified version using paraphrase because of uncertainty about its correctness" (DÖRNYEI; KORMOS, 1998, p. 372).

Deficiencies in the interlocutors' performance imply the use of different communication strategies by L2 speakers, since the source of the problem is the interlocutor involved in communication. Therefore, speakers may have difficulties comprehending the message the interlocutors intend to convey. In order to overcome these comprehension problems, Dörnyei and Kormos (1998) suggest that a meaning negotiation process between the interlocutor and the listener occurs. This process involves requests for repetition and/or explanation of doubtful and unfamiliar language structures, expression of non-understanding, requests or interpretive summaries in order to confirm or paraphrase what has been said and, finally, correction of some mistakes in the interlocutor's speech.

The research reviewed in this session show researchers' concerns with the several facets of communication and the interaction of these facets in building L2 speakers' oral competence. The next section presents the method we employed to investigate the relationship between CS use and L2 oral performance. 


\section{The study}

\section{Method}

\section{Research question}

The present study aimed at investigating the use of Communication Strategies (CS) and its relationship with L2 speech production by pursuing the following research question: Is there a relationship between the use of CS and L2 speech production in terms of speech rate?

\section{Participants}

Thirty L2 learners regularly attending an extra-curricular English course at a major university in Santa Catarina participated in the present study. Participants' age ranged from 15 to 34 years. These participants were divided into three groups of ten learners, according to their level of proficiency pre-intermediate, intermediate and advanced. Learners' proficiency level was determined by in-house proficiency exams applied by the university prior to data collection. Participants' scores on these exams were not made available to the researchers.

Considering that in order to participate in the study learners would need to be able to produce speech somewhat continuously, students from the first semester of the basic level were not selected. The 30 participants - 15 male and 15 female - were native speakers of Portuguese and, except for participant 18, who had taken part in an exchange program for about two years in the USA, none of the other participants had been exposed to the L2 community. For these participants, classes were the main source of L2 input.

Besides taking into consideration learners' level of proficiency, the researchers sought to select each group of ten participants from the same classroom, in order to guarantee that learners received the same quantity and quality of input in their L2 classes. However, this was not totally possible due to the fact that the pre-intermediate level was composed by small groups. Thus, for this level, it was necessary to select the 10 learners from two different groups. The number of participants was determined so as to allow for the statistical treatment of data, 30 being the minimum required. 


\section{Data collection procedures}

Data collection was carried out through the period corresponding to an academic semester at the university. The assessment of learners' oral production was undertaken through three oral narrative tasks: (1) narrating a fact in their lives, (2) narrating the story of a film, and (3) narrating the story presented in a sequence of pictures taken from a comic book. These tasks were selected because, as assumed by Lennon (1990), narratives are a usual modality of spoken language, familiar to most language users. Also, according to Ortega (1999, p. 122), story-retelling tasks seem appropriate to collect oral data " $(. .$.$) because narratives are familiar to most learners$ and can be manipulated naturally so as to be monologic rather than interactive in nature, and because there is a long tradition of using storyretelling in SLA research".

In order to determine the relationship between CS use and L2 speaking, learners in each proficiency level had their L2 production elicited three times during the semester, with a one-month interval between sessions. In the first session, participants in the three groups were asked to narrate a fact in their lives that had made them happy; in the second session, they were invited to tell the story of a movie they had seen and say whether they had liked it. In the third session, they were shown a sequence of pictures and were required to narrate the story the pictures depicted. Learners had five minutes to perform each task and were instructed not to interact with the researchers.

Before actually performing the tasks, each learner received a stimulus, so that they would feel more comfortable and self-confident to talk. The stimulus consisted of some questions referring to the topic learners would talk about. This was done in order to minimize the effects of eliciting speech in an experimental condition. Moreover, in the present study, participants were not instructed on how to perform a story-telling task neither were given time to plan what to say before actually executing the tasks. They were not allowed to ask for any vocabulary item they did not know or were in doubt about. A stopwatch was used to signal the beginning and the end of the tasks.

The 90 speech samples collected from the participants were taperecorded and transcribed ${ }^{2}$ by one of the researchers and double-checked

\footnotetext{
${ }^{2}$ Transcriptions followed these conventions: (.) pauses; (..) longer pauses; (:) lengthened sound; (...) unfinished utterance; (italics) emphasis on the utterance; (laughs) laughter particle and (?) question intonation.
} 
by an interrater. The samples comprise participants' oral production within the five minutes they were asked to talk. In cases in which they were not able to complete the time, longer silent pauses and expressions such as "I don't know what to say anymore" or "That's it" were considered to be the cut-off point in the transcriptions. Participants' speech that surpassed the allotted time was cut at the end of five minutes.

\section{Data analysis}

Data was analyzed quantitatively and the analysis aimed at establishing the relationship between the use of CS and learners' speech production by assessing the number of words participants produced per minute - that is, their speech rate - in each one of their narratives and correlating that with the number and type of CS they produced. The statistical test applied was Pearson Product Moment Coefficient of Correlation (twotailed). The assessment of speech rate took into consideration the total number of words produced by each speaker, including self-repetitions and corrections, since, as Levelt (1989) suggests, these devices indicate that speakers' speech-comprehension system is at work and that some kind of processing has started. The total number of words produced by each participant in each session was then divided by the total time (in seconds) each participant talked - also in each section. The resulting number was then multiplied by 60 so as to indicate the participant's speech rate (number of words produced by minute). Participants' use of CS was analyzed and classified according to Dörnyei and Kormos's (1998) taxonomy. Although Dörnyei and Kormos' (1998) framework gives the researcher the possibility to study CS use in interaction, the present study focused on the analysis of monologic speech samples, thus discarding the problem-solving mechanisms applied in two-way conversational settings .

\section{The taxonomy}

In this session, aiming at illustrating the strategies applied by the participants of the present study, we briefly present a summary of all categories of CS used to classify the data as well as some examples of participants' speech samples. 
TABLE 1

Examples of participants' use of CS according to Dörnyei and Kormos's (1998) taxonomy

\begin{tabular}{|c|c|}
\hline $\begin{array}{l}\text { Types of Problem-solving } \\
\text { mechanisms or CS }\end{array}$ & Examples of CS from participants' speech \\
\hline Message abandonment & $\begin{array}{l}\text { it's a cartoon an:d (.) the in the... I'll tell you about } \\
\text { this film because I like it }\end{array}$ \\
\hline Message reduction & the princess from the... his princess in the case \\
\hline Message replacement & he makes a: (.) he needs to to marry \\
\hline Code-switching & Then appears her her: fada-madrinha \\
\hline Approximation & Give her the the invite \\
\hline All-purpose-words & or things like this like this \\
\hline Complete omission & he: (一) "it's ok then I'll see what I will do" \\
\hline Foreignizing & when I was interessed a guy \\
\hline Grammatical word coinage & the second (.) was getting up on a tree \\
\hline Literal translation & eh: other thing strange \\
\hline Circumlocution & the: (.) husband of the cow \\
\hline Semantic word coinage & None Cs of this type was found in the data \\
\hline Restructuring & $\begin{array}{l}\text { Then I then eh we are (.) we go to to the mountain } \\
\text { then eh }\end{array}$ \\
\hline Direct appeal & Uhm como é que é cai (?) \\
\hline Indirect Appeal & I don't know abelhas abelhas \\
\hline Overgeneralization & in the: vulcan that eh the ring was maked \\
\hline Transfer & Chico Bento eh stay very nervous \\
\hline Grammatical Reduction & I cooking I washing I sleeping \\
\hline Phonological Retrieval & Good i...i (.) good eh (.) island \\
\hline Phonological Substitution & aí (—) jump the walk \\
\hline Phonological Reduction & Very del...eh eh delicate \\
\hline Lexicalized (filled) pauses & Well th...this movie \\
\hline Unfilled pauses & All periods of time participants did not produce speech \\
\hline Umming and erring & her son is $\mathbf{e h :} \mathbf{o h} \mathbf{~ e h}$ \\
\hline Lengthening a sound & the: the violence in our life \\
\hline Self-repetitions & she she bought a new house \\
\hline Error repair & looking after (.) he her \\
\hline Appropriacy repair & in the in this panic room \\
\hline Different repair & she's... I think she's had eh: (.) diabetes \\
\hline Rephrasing repair & $\begin{array}{l}\text { eh she's eh (.) separated of her husband né her } \\
\text { husband is not living with her and with her son }\end{array}$ \\
\hline Own-accuracy checks & recuper them eh them né (?) \\
\hline
\end{tabular}




\section{Results}

This section presents the results of the Pearson Product Moment Coefficient of Correlation (two-tailed), computed among number of strategies (STRAT), type of strategy (TYPE) and speech rate (SR). Results are presented according to participants' proficiency level. ${ }^{3}$

\section{CS versus Speech rate: L2 speech production in the Pre- Intermediate Group}

TAB. 2 reports the correlations calculated between the total number of CS (STRAT), the different types of CS (TYPE), and learners' speech rate (SR) in the first narrative task they performed: narrating a fact in their lives.

TABLE 2

Pearson Product Moment Coefficient of Correlation for the STRAT, TYPE and SR variables of Pre-Intermediate learners in sessions 1, 2 and 3

\begin{tabular}{l|c|c|c}
\hline & Session 1 & Session 2 & Session 3 \\
\hline \multirow{2}{*}{ STRAT } & SR & SR & SR \\
TYPE & .313 & -.206 & -.349 \\
\multicolumn{2}{r|}{$\mathrm{N}=10 \quad * \mathrm{p}<0.05 \quad * * \mathrm{p}<0.01$} & -.383 & -.509 \\
\hline \multicolumn{2}{r}{}
\end{tabular}

As can be seen in TAB. 2, results from the Pearson Product Moment Coefficient of Correlation between the total number of CS applied (STRAT), the total number of different types of CS (TYPE) and the speech rate (SR), including all pre-intermediate participants' scores, show that there is no statistically significant correlation among these variables. This finding can be interpreted as an indication that pre-intermediate learners' L2 oral production was not influenced by their use of CS across sessions, neither in terms of frequency use nor in terms of different types of strategies applied. According to these results, for the L2 pre-intermediate learners of this study, L2 speech production is not related to frequency or amount of CS use.

\footnotetext{
3 The number and type of strategy used by each participant in each recording session can be found in APPENDIX A. The measures for each participant's speech rate can be found in APPENDIX B.
} 


\section{CS versus Speech rate: L2 speech production in the Intermediate Group}

TAB. 3 displays the results of the correlations calculated among the total number of CS (STRAT), the total number of different types of CS (TYPE) and the speech rate (SR) of all intermediate learners in sessions 1, 2 and 3:

TABLE 3

Pearson Product Moment Coefficient of Correlation for the STRAT, TYPE and SR variables of Intermediate learners in sessions 1, 2 and 3

\begin{tabular}{|c|c|c|c|}
\hline & Session 1 & Session 2 & Session 3 \\
\hline & SR & SR & SR \\
\hline STRAT & .385 & .285 & -.219 \\
\hline TYPE & $.638^{*}$ & .363 & .287 \\
\hline
\end{tabular}

As can be seen in TAB. 3, the Pearson Product Moment Coefficient of Correlation indicates a statistically significant correlation between the different types of CS used in session 1 (TYPE1) and learners' speech rate in the same session (SR1), $N(10)=.638, p<0.05$. This result suggests that learners who applied a greater number of different types of CS tended to present a faster speech rate - that is, produced more fluent speech - and participants who applied a lower number of different types of CS tended to present a lower speech rate, implying less fluent speech production. However, no statistically significant correlations among STRAT, TYPE and SR variables were found in sessions 2 and 3, which might be interpreted as an indication that CS use is not consistently related to L2 speech production, neither in terms of frequency nor types of strategies.

\section{CS versus Speech rate: L2 speech production in the Advanced Group}

TAB. 4 shows the Pearson Product Moment Coefficient of Correlation computed among the total number of CS used by advanced learners, the total number of different types of CS and their respective speech rate in sessions 1, 2, and 3: 
TABLE 4

Pearson Product Moment Coefficient of Correlation for the STRAT, TYPE and SR variables of Advanced learners in sessions 1, 2 and 3

\begin{tabular}{|c|c|c|c|}
\hline & Session 1 & Session 2 & Session 3 \\
\hline & SR & SR & SR \\
\hline STRAT & -.043 & .346 & .201 \\
\hline TYPE & .127 & .359 & $.678^{*}$ \\
\hline
\end{tabular}

As can be observed from TAB. 4, in session 3, there is a statistically significant correlation between the total number of different types of CS (TYPE) and participants' speech rate (SR): $N(10)=.678, p<0.05$. This relationship shows that learners who applied a greater number of different types of CS presented a higher speech rate, that is, produced more fluent speech, whereas the ones who used a smaller number of different types of strategies presented a lower speech rate, speaking less fluently.

As is the case for intermediate learners, advanced students' oral development does not seem to be consistently related to the frequency and types of CS applied in sessions 1 and 2, since no statistically significant correlation was found among STRAT, TYPE and SR variables in these sessions.

\section{Discussion of Results}

Concerning the research question addressed by the present study, whether CS use is related to $\mathrm{L} 2$ speech performance in terms of speech rate, no strong evidence was found in favor of this relationship. The two statistically significant correlations found in the analysis - one between the total number of different types of strategy and speech rate, for the intermediate group in session 1 , and the other between the same variables in session 3 for the advanced group - might be taken as an indication that, as learners advance in their knowledge of the language, their speech production, at least in terms of fluency, tends to improve. However, since this relationship was not maintained across sessions and across levels, these findings must be taken with caution.

Reiterating, the intermediate learners, in the first recording session only, tended to use a greater number of different types of CS and to speak 
faster than the other participants. The advanced learners, in the third recording session only, also used a greater number of different types of CS and tended to speak faster than the other two groups. Intermediate learners used CS such as transfer, grammatical reduction, unfilled pauses, umming and erring, lengthening and self-repetitions, all of them with a high frequency of use. Examples of theses CS can be found in the following excerpts:

$\rightarrow$ “...I: I try and I: I win I win I pass for (.) medicine..." (Participant 32)

$\rightarrow$ “...I camed to: come to to Blumenau..." (Participant 31)

$\rightarrow$ "...eh they both they both which crashed the car was wrong..." (Participant 27)

Advanced learners, likewise, used CS such as grammatical reductions, unfilled pauses, lengthening a sound, umming and erring, and selfrepetitions. Some of these CS can be seen in the following excerpts

$\rightarrow$ “...not to be: not to be: uhm (.) not to be: (.) to not to not the bees didn't attack him..." (Participant 7)

$\rightarrow$ “...she's fathers ..." (Participant 21)

$\rightarrow$ "...Chico Bento and (.) decide to: (.) to (.) to go eh in a tree..." (Partcipant 8)

The variability in these results and the lack of a statistically significant correlation between CS use and L2 oral fluency may be related to the temporal variable used to measure oral production development: speech rate. In other words, it may be that speech rate alone is not enough to capture the relationship between CS use and L2 fluency. It would be necessary to look at other variables in participants' speech, in order to investigate the relationship between CS frequency of occurrence, total number of different types of CS and L2 fluency development.

As shown in the L2 speech production literature, fluency has been considered an ill-defined concept, since it may encompass a series of linguistic, sociolinguistic and psycholinguistic phenomena (FREED, 1995). According to Lennon (1990), fluency seems to be conceived in two distinct senses - the broad and the narrow sense. Whereas the former deals with a general term referring to oral proficiency as a whole, the latter suggests that fluency is only one of the components of oral proficiency.

Schmidt (1992) sees fluency as a temporal phenomenon and argues that fluent speech relies upon procedural knowledge, being, consequently, automatic and requiring little attention and effort. Non-fluent speech, on the other hand, is effortful, requires attentional resources, is time-consuming 
and likely to present many hesitations and difficulties in the combination of words.

Besides considering the temporal characteristics of fluency, Pawley and Syder (1983) suggest that fluency is a result of the speaker's control on a body of lexicalized sentence stems ${ }^{4}$ which can be fully and automatically retrieved from memory in the form of chunks and used to minimize the effort of encoding new lexical items, thus, freeing the speakers' attentional resources to the production of new stretches of speech. In all, what we want to argue is that speech rate, alone, may be too general a variable to reflect accurately these aspects of fluent speech production.

In addition, the nature of tasks learners were asked to perform (narratives) and the mental energy (amount of attentional resources) they had to apply in order to perform the tasks might have contributed to the lack of a significant correlation between strategy use and performance. Since a great part of fluent speech seems to rely on lexicalized chunks, easily and automatically retrievable from memory (PAWLEY; SYDER, 1983), it may be that the participants of the present study had problems in accessing and retrieving formulaic language, either because of an incomplete knowledge base or because of overload in their working memory resources. With their attentional resources limited by lack of automatized knowledge, speakers tend to prioritize what to give attention to - in the case of the present study, speakers might have chosen to give priority to encoding processes and not to the use and frequency of different types of communication strategies.

As most of the CS used by participants of the present study seem to have been applied in order to compensate for lexical difficulties, it appears safe to assume that most constraints on fluency improvement are related to problems in the formulator, since it is in this processing component that the translation of concepts into linguistic structures by means of grammatical and phonological encoding occurs (LEVELT, 1989). According to Levelt (1989), the formulator is highly automatic and, therefore, requires a great amount of procedural knowledge. Once L2 speakers have not developed

\footnotetext{
${ }^{4}$ According to Pawley and Syder (1983), a lexicalized sentence stem is "a unit of clause length or longer whose grammatical form and lexical content is wholly or largely fixed; its fixed elements form a standard label for a culturally recognized concept" (p. 191). A lexicalized item is considered to be a conventional label for a conventional concept in the speech community (p. 209).
} 
such automaticity, it is likely that they will find several problems while encoding their messages. Automaticity and procedural knowledge are also assumed to be essential in order to map a semantic form to a lemma.

As claimed by De Bot and Schreuder (1993), a new processing component is necessary to connect pieces of conceptual information to their lemma representations - the verbalizer ( Vbl). According to them, "the $\mathrm{Vbl}$ module is responsible for cutting up the fragment in chunks that can be matched with the semantic information associated with the different lemmas in the mental lexicon" (DE BOT; SCHREUDER, 1993, p. 193). However, this is only possible if there is a perfect match between all semantic structures and their lemma counterparts. But, in the case of L2 learners, including the participants of the present study, not all requirements of the semantic form may be available in the mental lexicon or can be retrieved. In addition, learners may also have incomplete semantic specifications for some lexical items, which causes a mismatch between what is intended and what is possible to say.

Again, our point is that the speech rate variable used to measure L2 oral fluency in the present study, being a temporal variable, might not have captured all of the processes that take place in the formulator and the verbalizer, which consist of processes related to learners' lack of automaticity and procedural knowledge, insufficient semantic specifications and lemma representations, and limited command of the L2 linguistic system. Together, these aspects are all likely to prevent learners from improving their oral ability.

It could also be the case that, as suggested by Lennon (1990), in order to examine L2 speaking - and fluency, in particular - several other quantifiable performance features, besides speech rate, need to be assessed. These would include mean length of run, mean length of pauses, selfrepetitions, and self-corrections. We would extend this claim by proposing that, to examine L2 speech production - including fluency and CS use we need to look at other dimensions of performance, accuracy, complexity, lexical density being a case in point (SKEHAN, 1998).

\section{Final Remarks}

As previously stated, the present study was carried out in order to investigate the relationship between CS use and learners' L2 speech production in terms of speech rate. The theoretical and methodological bases for this study comprised the existing literature on Communication Strategies 
and L2 Speech Production. Nevertheless, research in both areas has superficially attempted to relate CS use and speech production in an L2 from a quantitative perspective. In this sense, this study is tentative and exploratory in that it sought to address CS use in a sort of longitudinal fashion and across proficiency levels.

Summing up, results from the present study show that only two statistically significant correlations were found in the data. These were related to the type of CS used and not to the frequency with which they were applied. Given this specific finding, the present study seems to show an apparent weak relationship between CS and L2 speech production and some issues regarding future research deserve further attention.

First, results cannot be generalized due to the sample size investigated. It would be possible to state findings more strongly if the study had been carried out with a larger number of students and in a more naturalistic setting. Second, the type of task selected to elicit speech production was a narrative. In the L2 speech production literature, it is claimed that narratives are commonly practiced by learners in class. However, the fact that learners were asked to talk alone for 5 minutes might have caused a strange feeling for some of them. Future research could ask learners to perform dialogic tasks. Third, no kind of data collection instrument was applied prior to the performance of the tasks in order to investigate which topics learners would like to talk about. The topics were determined by the researchers whose main concern was to provide learners with a motivating and interesting topic to talk - one that would not bring them to some delicate and uncomfortable situation. For future research, questionnaires aiming at defining the topics of the narratives could be applied before data collection. Finally, the present study drew upon speech rate scores to measure fluency development, following most studies on L2 speech production. Although it has been shown to be a salient feature of fluent L2 speakers, speech rate did not seem to be an adequate variable to assess the relationship between CS use and oral performance. Thus, in future studies, other temporal variables may be used to examine oral fluency and these can include length of run, filled and unfilled pauses, hesitations and repair phenomena. In addition, an analysis could be carried out taking into account other aspects of language production, such as accuracy, complexity and lexical density.

In any event, L2 speech production is a complex cognitive skill which may present several particularities across proficiency levels and task types. 
As there has been a trend to follow a more communicative perspective in the teaching of an $\mathrm{L} 2$, and speaking has been taken as synonym of language competence in educational as well as in professional settings, much more research is needed for us to grasp the complexity involved in speech production.

\section{References}

BIALYSTOK, E. Communication Strategies: A psychological analysis of second-language use. Oxford: Basil Blackwell, 1990.

BIALYSTOK, E. Some factors in the selection and implementation of communication strategies. In: FAERCH, C.; KASPER, G. (Ed.). Strategies in interlanguage communication. London: Longman, 1983 p. 79-99.

BONGAERTS, T.; POULISSE, N. Communication Strategies in L1 and L2: same or different? Applied Linguistics, Oxford, v. 10, n. 3, p. 253-268, 1989.

CHEN, S. Q. A study of communication strategies in interlanguage production by Chinese EFL learners. Language Learning, Oxford, 40, p. 155-87, 1990.

DE BOT, K.; SCHREUDER, R. Word Production and the Bilingual Lexicon. In: SCHREUDER, R.; WELTENS, B. (Ed.). The Bilingual lexicon. Amsterdam: John Benjamins, 1993.

DE BOT, K. A Bilingual Production Model: Levelt's 'Speaking' Model adapted. Applied Linguistics, Oxford, v. 13, n. 1, p. 1-24, 1992.

DÖRNYEI, Z.; KORMOS, J. Problem-Solving Mechanisms in L2 Communication: A Psycholinguistic Perspective. Studies in Second Language Acquisition, Cambridge, v. 20, n. 3, p. 349-385, 1998.

FAERCH, C.; KASPER, G. (Ed.). Strategies in Interlanguage Communication. London: Longman, 1983.

FLYMAN, A. Communication strategies in French as a foreign language. Working Papers. Lund, v. 46, p. 57-73, 1997.

FREED, B. F. What makes us think that students who study abroad become fluent? In: FREED, B. F. (Ed.). Second Language Acquisition in a Study Abroad Context. Philadelphia: John Benjamins, 1995. p.123-148 .

KASPER, G.; KELLERMAN. E. Communication Strategies: Psycholinguistic and Sociolinguistic Perspectives. New York: Longman, 1997.

LENNON, P. Investigating Fluency in EFL: a qualitative approach. Language Learning, Oxford, v. 40, n. 3, p. 387-417, 1990. 
LEVELT, W. J. M. Speaking: from intention to articulation. Cambridge, MA: MIT Press, 1989.

MANCHÓN, R. M. Fostering the autonomous use of communication strategies in the foreign language classroom. Links \& Letters, Barcelona, v. 7, p.13-27, 2000.

ORTEGA, L. Planning and focus on form in L2 oral performance. Studies in Second Language Acquisition, Cambridge, v. 21, n. 1, p. 109-148, 1999.

PALMBERG, R. Solving Communicative Problems in Interlanguage. Interlanguage Studies Bulletin, Amsterdam, v. 8, n.2, p. 35-49, 1984.

PARIBAKHT, T. Strategic competence and Language Proficiency. Applied Linguistics, Oxford, v. 6, n. 2, p. 132-46, 1985.

PAWLEY, A.; SYDER, F. H. Two puzzles for linguistic theory: nativelike selection and nativelike fluency. In: RICHARDS, J.C.; SCHMIDT, R.W. (Ed.). Language and Communication. New York: Longman, 1983. p. 191-226.

POULISSE, N. Problems and solutions in the classification of compensatory strategies. Second Language Research, Oxford, v. 3, n. 2, p. 141-153, 1987. POULISSE, N.; BONGAERTS, T. First language use in second language production. Applied Linguistics, Oxford, v. 15, n.1, p. 36-57, 1994.

POULISSE, N., BONGAERTS, T.; KELLERMAN, E. The use of retrospective verbal reports in the analysis of compensatory strategies. In: FAERCH, C.; KASPER, G. (Eds.). Introspection in second language research. Clevedon, Uk: Multilingual Matters, 1987. p 213-229.

POULISSE, N.; SCHILS, E. The influence of task- and proficiency-related factors on the use of compensatory strategies: a quantitative analysis. Language Learning. Oxford, v. 39, n. 1, p. 15-48, 1989.

POULISSE, N. Language Production in Bilinguals. In: DE GROOT, A. M. B.; KROLL, J. F. (Ed.). Tutorials in bilingualism: psycholinguistic perspectives. Mahwah, N. J.: LEA, 1997. p. 201-224.

POULISSE, N. A Theoretical Account of Lexical Communication Strategies. In: SCHREUDER, R.; WELTENS, B. (Ed.). The Bilingual lexicon. Amsterdam: John Benjamins, 1993. p. 157-190.

POULISSE, N. Communication strategies in a second language. In: BROWN, K. (Ed.). The encyclopedia of language and linguistics, Oxford, v. 2. Oxford: Elservier, 1994. p 620-624.

RICHARD, J. C.; PLATT, J; PLATT, H. Longman Dictionary of Language Teaching and Applied Linguistics. London: Longman, 1992. 
RODRIGUES, C. Estratégias de Comunicação em uma língua estrangeira. A perspectiva da sala de aula. Linguagem E Ensino, Pelotas, v. 2, n. 1, p. 11-35, 1999.

SCHMIDT, R. Psychological mechanisms underlying second language fluency. Studies in Second Language Acquisition, Cambridge, v. 14, n. 3, p. 357-385, 1992.

SKEHAN, P. A cognitive approach to language learning. Oxford: Oxford University Press, 1988.

TARONE, E. Communication strategies, foreigner talk, and repair in interlanguage. Language Learning, Oxford, v. 30, n. 4, p. 417-431, 1980.

VARADI, T. Strategies of target language learner communication: message adjustment. In: Faerch, C.; Kasper, G. (Ed.). Strategies in interlanguage communication. London: Longman, 1983. p. 79-99.

YARMOHAMMADI, L.; SEIF, S. More on Communication Strategies: classification, resources, frequency and underlying processes. IRAL. Oxford, v. 30, n.2., p. 223-232, 1992. 


\section{APPENDICES}

\section{Appendix A - Number and type of CS applied by participants}

The Pre-Intermediate Group - session 1

\begin{tabular}{|c|c|c|c|c|c|c|c|c|c|c|c|}
\hline \multirow[b]{2}{*}{ Types of CS } & \multicolumn{10}{|c|}{ Participants } & \multirow{2}{*}{$\begin{array}{r}\text { Frequency } \\
\text { of CS use }\end{array}$} \\
\hline & 1 & 2 & 5 & 6 & 12 & 13 & 14 & 16 & 17 & 33 & \\
\hline Message abandonment & & 1 & 1 & & & & & 1 & 2 & & 5 \\
\hline Message reduction & & & & & & & & & 1 & & 1 \\
\hline Message replacement & & & & & & & 1 & & 1 & & \\
\hline Code-switching & & & & 1 & 5 & 4 & 1 & 2 & 1 & 1 & 15 \\
\hline Approximation & & & 1 & & & & & & & & 1 \\
\hline All-purpose-words & & & & & & & & & & & \\
\hline Complete omission & & & & 2 & & & & & & & 2 \\
\hline Foreignizing & & & 2 & 2 & 1 & & & & 3 & & 8 \\
\hline Grammatical word coinage & & & & & & & & & & & \\
\hline Literal translation & & & & & & & & & & & \\
\hline Circumlocution & & & & & & & & & & & \\
\hline Semantic word coinage & & & & & & & & & & & \\
\hline Restructuring & & 3 & 1 & & 1 & 1 & & 1 & 2 & 3 & 12 \\
\hline Direct appeal & & & & & & & 1 & & & 1 & \\
\hline Indirect Appeal & & & & & & & & 2 & & & 2 \\
\hline Overgeneralization & 1 & & & 2 & & & 4 & & 3 & 4 & 14 \\
\hline Transfer & 1 & 2 & 2 & 5 & 1 & 3 & 3 & 2 & 6 & 1 & 26 \\
\hline Grammatical Reduction & 5 & 10 & 16 & 13 & 10 & 7 & 6 & 5 & 7 & 12 & 91 \\
\hline Phonological Retrieval & & 1 & 2 & 2 & 2 & & 1 & & 2 & 1 & 11 \\
\hline Phonological Substitution & & & & & & & & & 2 & & 2 \\
\hline $\begin{array}{l}\text { Phonological Reduction } \\
\text { (mumbling) }\end{array}$ & & & & & & & & 1 & 1 & & \\
\hline Filled pauses (fillers) & & & 2 & & & & & 1 & 3 & & 6 \\
\hline Unfilled pauses & 17 & 22 & 28 & 15 & 6 & 15 & 25 & 24 & 8 & 11 & 171 \\
\hline Umming and erring & 2 & 16 & 11 & 38 & 13 & 8 & 16 & 3 & 10 & 14 & 131 \\
\hline Lengthening a sound & 6 & 7 & 24 & 18 & 7 & 6 & 12 & 4 & 35 & 20 & 139 \\
\hline Self-repetitions & 3 & 22 & 23 & 23 & 3 & 1 & 10 & 5 & 14 & 23 & 127 \\
\hline Error repair & 1 & 3 & 2 & 1 & 2 & 1 & & 1 & 5 & 6 & 22 \\
\hline Appropriacy repair & & & & 1 & & & 1 & & 1 & & 3 \\
\hline Different repair & & & & & & & & & & & \\
\hline Rephrasing repair & & & & & & & & & & & \\
\hline Own-accuracy checks & & & & & & & & & & & \\
\hline $\begin{array}{l}\text { Total number of CS } \\
\text { per participant }\end{array}$ & 36 & 87 & 116 & 123 & 51 & 46 & 80 & 51 & 105 & 97 & \\
\hline $\begin{array}{l}\text { Total number of different } \\
\text { types of CS per participant }\end{array}$ & 8 & 10 & 14 & 13 & 11 & 9 & 11 & 12 & 17 & 12 & \\
\hline
\end{tabular}


The Pre-Intermediate Group - session 2

\begin{tabular}{|c|c|c|c|c|c|c|c|c|c|c|c|}
\hline \multirow[b]{2}{*}{ Types of CS } & \multicolumn{10}{|c|}{ Participants } & \multirow{2}{*}{$\begin{array}{r}\text { Frequency } \\
\text { of CS use }\end{array}$} \\
\hline & 1 & 2 & 5 & 6 & 12 & 13 & 14 & 16 & 17 & 33 & \\
\hline Message abandonment & & 1 & 1 & 1 & 1 & 2 & & 1 & 1 & & 8 \\
\hline Message reduction & & & & & 3 & & & & & & 3 \\
\hline Message replacement & & & & & 2 & & 1 & 1 & & & 4 \\
\hline Code-switching & & & & 2 & 12 & 15 & 1 & 4 & & & 34 \\
\hline Approximation & & & & & & & & & & & \\
\hline All-purpose-words & & & & & & & 1 & & & & 1 \\
\hline Complete omission & & & 2 & 1 & 1 & & 1 & 1 & & 1 & 7 \\
\hline Foreignizing & & & & & & 1 & & 14 & & 1 & 16 \\
\hline Grammatical word coinage & & & & & & & & & & & \\
\hline Literal translation & & & & & & & & & & & \\
\hline Circumlocution & & & & & & & & & & & \\
\hline Semantic word coinage & & & & & & & & & & & \\
\hline Restructuring & & & 1 & 1 & & 1 & 1 & 1 & & 1 & 6 \\
\hline Direct appeal & & & & & & & & 1 & & & 1 \\
\hline Indirect Appeal & & & & 3 & & & & & & & 3 \\
\hline Overgeneralization & 1 & 1 & & & 2 & & & 1 & & 1 & 6 \\
\hline Transfer & 5 & 1 & 1 & 4 & 3 & 3 & 4 & 5 & 8 & 3 & 37 \\
\hline Grammatical Reduction & 3 & 6 & 4 & 8 & 13 & 13 & 7 & 8 & 3 & 18 & 83 \\
\hline Phonological Retrieval & 1 & 1 & 1 & 4 & 2 & 1 & 1 & 3 & 2 & 1 & 17 \\
\hline Pbonological Substitution & & & 1 & 1 & & & & & & & 2 \\
\hline $\begin{array}{l}\text { Phonological Reduction } \\
\text { (mumbling) }\end{array}$ & & & 3 & & 1 & 1 & 1 & 1 & 7 & & \\
\hline Filled pauses (fillers) & & 3 & & 11 & 3 & & & 1 & & & 18 \\
\hline Unfilled pauses & 9 & 4 & 13 & 18 & 18 & 11 & 15 & 19 & 15 & 3 & 125 \\
\hline Umming and erring & 4 & 21 & 16 & 26 & 34 & 27 & 31 & 10 & 14 & 16 & 199 \\
\hline Lengthening a sound & 10 & 3 & 15 & 16 & 22 & 16 & 14 & 18 & 19 & 26 & 159 \\
\hline Self-repetitions & 3 & 3 & 23 & 17 & 3 & 3 & 10 & 18 & 12 & 12 & 104 \\
\hline Error repair & 2 & 4 & 2 & & 5 & 7 & 1 & 3 & 4 & 6 & 34 \\
\hline Appropriacy repair & & & 1 & 1 & 1 & & & & & 2 & 5 \\
\hline Different repair & 1 & & & & & & & & & & 1 \\
\hline Rephrasing repair & & & & & & & & & & & \\
\hline Own-accuracy checks & & & & & & 1 & & & & & 1 \\
\hline $\begin{array}{l}\text { Total number of CS } \\
\text { per participant }\end{array}$ & 39 & 48 & 84 & 114 & 126 & 102 & 89 & 110 & 78 & 91 & \\
\hline $\begin{array}{l}\text { Total number of different } \\
\text { types of CS per participant }\end{array}$ & 10 & 11 & 14 & 15 & 17 & 14 & 14 & 18 & 10 & 13 & \\
\hline
\end{tabular}


The Pre-Intermediate Group - session 3

\begin{tabular}{|c|c|c|c|c|c|c|c|c|c|c|c|}
\hline \multirow[b]{2}{*}{ Types of CS } & \multicolumn{10}{|c|}{ Participants } & \multirow{2}{*}{$\begin{array}{r}\text { Frequency } \\
\text { of CS use }\end{array}$} \\
\hline & 1 & 2 & 5 & 6 & 12 & 13 & 14 & 16 & 17 & 33 & \\
\hline Message abandonment & & & 1 & & 1 & 1 & 1 & 3 & & & 7 \\
\hline Message reduction & & 1 & & & & 1 & & & & & 2 \\
\hline Message replacement & & 2 & 3 & & & & & 1 & & & 6 \\
\hline Code-switching & & & & 4 & 12 & 5 & 3 & 6 & & 1 & 31 \\
\hline Approximation & & 2 & 1 & 3 & 4 & 1 & & 1 & 1 & 4 & 17 \\
\hline All-purpose-words & & & 1 & & & & & & & & 1 \\
\hline Complete omission & & & & 6 & & & 3 & & & 1 & 10 \\
\hline Foreignizing & & & & & 1 & & & 2 & 1 & & 4 \\
\hline Grammatical word coinage & & 2 & & & & & & & & & 2 \\
\hline Literal translation & & & & & & & & 1 & 3 & & 4 \\
\hline Circumlocution & & & & & & & & & 2 & & 2 \\
\hline Semantic word coinage & & & & & & & & & & & \\
\hline Restructuring & & & & & & 2 & & & & & 2 \\
\hline Direct appeal & & & & & 1 & & & 1 & & & 2 \\
\hline Indirect Appeal & & & & 2 & & & & & & & 2 \\
\hline Overgeneralization & & 1 & & & & & 1 & & & & 2 \\
\hline Transfer & 1 & 1 & 5 & 5 & 11 & 4 & 3 & 2 & 3 & 6 & 41 \\
\hline Grammatical Reduction & 4 & 9 & 8 & 16 & 10 & 8 & 7 & 8 & 3 & 3 & 76 \\
\hline Phonological Retrieval & 1 & & & 2 & 2 & 1 & 1 & 1 & & 1 & 9 \\
\hline Phonological Substitution & & & & 4 & 1 & 1 & & 1 & & & 7 \\
\hline $\begin{array}{l}\text { Phonological Reduction } \\
\text { (mumbling) }\end{array}$ & 1 & & 2 & & & & & & 4 & & \\
\hline Filled pauses (fillers) & & & 1 & 8 & 5 & 1 & & & 1 & 1 & 17 \\
\hline Unfilled pauses & 22 & 20 & 29 & 17 & 10 & 12 & 21 & 18 & 14 & 8 & 171 \\
\hline Umming and erring & 1 & 10 & 15 & 30 & 34 & 13 & 12 & 10 & 14 & 10 & 149 \\
\hline Lengthening a sound & 8 & 13 & 22 & 21 & 22 & 9 & 11 & 22 & 25 & 14 & 167 \\
\hline Self-repetitions & 5 & 17 & 16 & 9 & 4 & 6 & 7 & 14 & 12 & 8 & 98 \\
\hline Error repair & 3 & 5 & 2 & 4 & 6 & 3 & 1 & 4 & 1 & 3 & 32 \\
\hline Appropriacy repair & & & & & & & 1 & & 3 & & 4 \\
\hline Different repair & & & & & & & & 1 & & & 1 \\
\hline Rephrasing repair & & & 3 & & & & 1 & 1 & & & 5 \\
\hline Own-accuracy checks & & & & & & & & & & & \\
\hline $\begin{array}{l}\text { Total number of CS } \\
\text { per participant }\end{array}$ & 46 & 82 & 108 & 133 & 123 & 67 & 73 & 96 & 86 & 61 & \\
\hline $\begin{array}{l}\text { Total number of different } \\
\text { types of CS per participant }\end{array}$ & 9 & 11 & 13 & 16 & 14 & 14 & 14 & 19 & 14 & 13 & \\
\hline
\end{tabular}


The Intermediate Group - session 1

\begin{tabular}{|c|c|c|c|c|c|c|c|c|c|c|c|}
\hline \multirow[b]{2}{*}{ Types of CS } & \multicolumn{10}{|c|}{ Participants } & \multirow{2}{*}{$\begin{array}{r}\text { Frequency } \\
\text { of CS use }\end{array}$} \\
\hline & 22 & 23 & 24 & 25 & 26 & 27 & 28 & 29 & 31 & 32 & \\
\hline Message abandonment & & 1 & & 1 & 3 & 1 & 1 & 1 & 1 & 1 & 10 \\
\hline Message reduction & & & & & 2 & & 1 & & & & 3 \\
\hline Message replacement & & & & 1 & & & & 1 & & & 2 \\
\hline Code-switching & & 1 & & 10 & & & & & 3 & 2 & 16 \\
\hline Approximation & & & & & 1 & & & 1 & & 1 & 3 \\
\hline All-purpose-words & & & 1 & & 2 & & 3 & 4 & & 1 & 11 \\
\hline Complete omission & & & & & & & 2 & 4 & & 1 & 7 \\
\hline Foreignizing & & & & 1 & 4 & 1 & 1 & 2 & & & 9 \\
\hline Grammatical word coinage & & & & 1 & & & & & & & 1 \\
\hline Literal translation & & & 1 & & & & & & & & 1 \\
\hline Circumlocution & & & & & & & & & 1 & & 1 \\
\hline \multicolumn{12}{|l|}{ Semantic word coinage } \\
\hline Restructuring & 2 & 1 & 1 & 3 & 2 & & 1 & 1 & & & 11 \\
\hline Direct appeal & & 1 & & & & 1 & & & & & 2 \\
\hline Indirect Appeal & & & & 2 & 1 & & & & 1 & & 4 \\
\hline Overgeneralization & 1 & & 1 & 1 & 1 & & & & 1 & & 5 \\
\hline Transfer & 1 & 2 & 12 & 8 & 6 & 5 & 5 & 1 & 4 & 5 & 49 \\
\hline Grammatical Reduction & 9 & 12 & 15 & 26 & 20 & 27 & 13 & 26 & 12 & 29 & 189 \\
\hline Phonological Retrieval & 1 & 2 & & 4 & 2 & & 4 & 6 & 4 & 1 & 24 \\
\hline Phonological Substitution & & & & & & & & & & & \\
\hline $\begin{array}{l}\text { Phonological Reduction } \\
\text { (mumbling) }\end{array}$ & & & 1 & & & & & & & & 1 \\
\hline Filled pauses (fillers) & & & 5 & 6 & 2 & & & & 4 & 28 & 45 \\
\hline Unfilled pauses & 22 & 16 & 24 & 11 & 7 & 22 & 5 & 24 & 9 & 17 & 157 \\
\hline Umming and erring & 17 & 24 & 6 & 29 & 29 & 10 & 22 & 8 & 17 & 14 & 176 \\
\hline Lengthening a sound & 16 & 5 & 10 & 16 & 13 & 13 & 33 & 10 & 56 & 11 & 183 \\
\hline Self-repetitions & 19 & 25 & 4 & 60 & 22 & 14 & 23 & 26 & 29 & 26 & 248 \\
\hline Error repair & 6 & 4 & 1 & 10 & 2 & 2 & & 1 & 3 & 5 & 34 \\
\hline Appropriacy repair & & & & 2 & 1 & 3 & 5 & 4 & & 2 & 17 \\
\hline Different repair & & & & & & & & & & & \\
\hline Rephrasing repair & 2 & 2 & & 4 & 2 & 2 & & 2 & 1 & 3 & 18 \\
\hline Own-accuracy checks & & & & & & & & & & & \\
\hline $\begin{array}{l}\text { Total number of CS } \\
\text { per participant }\end{array}$ & 96 & 96 & 82 & 196 & 122 & 101 & 119 & 122 & 146 & 147 & \\
\hline $\begin{array}{l}\text { Total number of different } \\
\text { types of CS per participant }\end{array}$ & 11 & 13 & 13 & 19 & 19 & 12 & 14 & 17 & 15 & 16 & \\
\hline
\end{tabular}


The Intermediate Group - session 2

\begin{tabular}{|c|c|c|c|c|c|c|c|c|c|c|c|}
\hline \multirow[b]{2}{*}{ Types of CS } & \multicolumn{10}{|c|}{ Participants } & \multirow{2}{*}{$\begin{array}{r}\text { Frequency } \\
\text { of CS use }\end{array}$} \\
\hline & 22 & 23 & 24 & 25 & 26 & 27 & 28 & 29 & 31 & 32 & \\
\hline $\begin{array}{l}\text { Message abandonment } \\
\text { Message reduction } \\
\text { Message replacement }\end{array}$ & & 1 & & 2 & 4 & 1 & & 1 & 1 & 3 & $\begin{array}{r}11 \\
2\end{array}$ \\
\hline Code-switching & 1 & 2 & & 2 & 10 & 1 & 1 & & 3 & 1 & 21 \\
\hline $\begin{array}{l}\text { Approximation } \\
\text { All-purpose-words }\end{array}$ & & 3 & & 1 & 3 & 1 & & & & & 8 \\
\hline Complete omission & & & 2 & 1 & 1 & 2 & 1 & 3 & 1 & 2 & 13 \\
\hline Foreignizing & & & 1 & & 2 & 1 & & & & 2 & 6 \\
\hline Grammatical word coinage & & 2 & 1 & 1 & & & & & & & 4 \\
\hline $\begin{array}{l}\text { Literal translation } \\
\text { Circumlocution } \\
\text { Semantic word coinage }\end{array}$ & 1 & 1 & & 3 & & & & & & & 5 \\
\hline Restructuring & & & & 1 & 2 & 1 & 2 & & 1 & & 7 \\
\hline Direct appeal & & 2 & & & & & & & & & 2 \\
\hline Indirect Appeal & & & & 1 & 3 & & & & & 1 & 5 \\
\hline Overgeneralization & 3 & 1 & & 3 & 2 & & 1 & & 2 & & 12 \\
\hline Transfer & 1 & 1 & 4 & 1 & 9 & 5 & 4 & 8 & 5 & 7 & 45 \\
\hline Grammatical Reduction & 9 & 14 & 6 & 8 & 15 & 20 & 15 & 13 & 5 & 22 & 127 \\
\hline Phonological Retrieval & 3 & 5 & 1 & 5 & 2 & 1 & 2 & 5 & 4 & 8 & 36 \\
\hline Phonological Substitution & & & 1 & & & & & & & & 1 \\
\hline $\begin{array}{l}\text { Phonological Reduction } \\
\text { (mumbling) }\end{array}$ & & & & 3 & & & 2 & & & & 5 \\
\hline Filled pauses (fillers) & & & & 3 & 1 & & & & & 22 & 26 \\
\hline Unfilled pauses & 15 & 11 & 22 & 15 & 16 & 37 & 12 & 26 & 13 & 20 & 187 \\
\hline Umming and erring & 18 & 40 & 4 & 14 & 41 & 9 & 17 & 5 & 17 & 24 & 189 \\
\hline Lengthening a sound & 27 & 23 & 20 & 14 & 21 & 19 & 43 & 10 & 27 & 26 & 230 \\
\hline Self-repetitions & 26 & 38 & 4 & 20 & 30 & 12 & 16 & 14 & 13 & 19 & 192 \\
\hline Error repair & 5 & 2 & 2 & 2 & 5 & 2 & 3 & 2 & 3 & 2 & 28 \\
\hline Appropriacy repair & 1 & 2 & 2 & 1 & 3 & 11 & 1 & 1 & 1 & 4 & 27 \\
\hline Different repair & & & & & & & 1 & & & 2 & 3 \\
\hline $\begin{array}{l}\text { Rephrasing repair } \\
\text { Own-accuracy checks }\end{array}$ & 3 & & 2 & 2 & 7 & 3 & 1 & 1 & & 5 & 24 \\
\hline $\begin{array}{l}\text { Total number of CS per } \\
\text { participant }\end{array}$ & 113 & 151 & 72 & 100 & 179 & 126 & 120 & 89 & 96 & 170 & \\
\hline $\begin{array}{l}\text { Total number of different } \\
\text { types of CS per participant }\end{array}$ & 13 & 17 & 14 & 20 & 20 & 16 & 15 & 12 & 14 & 17 & \\
\hline
\end{tabular}


The Intermediate Group - session 3

\begin{tabular}{|c|c|c|c|c|c|c|c|c|c|c|c|}
\hline \multirow[b]{2}{*}{ Types of CS } & \multicolumn{10}{|c|}{ Participants } & \multirow{2}{*}{$\begin{array}{r}\text { Frequency } \\
\text { of CS use }\end{array}$} \\
\hline & \multirow[t]{2}{*}{22} & \multirow[t]{2}{*}{23} & 24 & \multirow{2}{*}{$\begin{array}{r}25 \\
1\end{array}$} & \multirow{2}{*}{$\begin{array}{r}26 \\
2\end{array}$} & \multirow[t]{2}{*}{27} & 28 & 29 & 31 & 32 & \\
\hline Message abandonment & & & & & & & & & & 2 & 5 \\
\hline Message reduction & 1 & & & & & & & & & & 1 \\
\hline Message replacement & & & & & & & & & & & \\
\hline Code-switching & & 3 & & 7 & 6 & & 1 & 2 & 3 & 1 & 23 \\
\hline Approximation & 3 & 4 & 1 & 1 & 1 & 1 & 1 & 3 & & 3 & 18 \\
\hline All-purpose-words & & & & & & & & & & & \\
\hline Complete omission & & 3 & & 1 & & & & 1 & & 2 & 7 \\
\hline Foreignizing & & 1 & & & & & 1 & & & & 2 \\
\hline Grammatical word coinage & & 1 & & & & & & & & & 1 \\
\hline Literal translation & & & & & & 1 & & & & & 1 \\
\hline Circumlocution & & & & & & & & & & 1 & 1 \\
\hline Semantic word coinage & & & & & & & & & & & \\
\hline Restructuring & & & & 1 & 1 & 1 & & & & & 3 \\
\hline Direct appeal & & & & & & & & & & & \\
\hline Indirect Appeal & & & & 2 & 2 & & & 1 & & & 5 \\
\hline Overgeneralization & & & & 1 & & & & & & & 1 \\
\hline Transfer & 1 & 4 & 1 & 8 & 2 & 1 & & 2 & 3 & 1 & 23 \\
\hline Grammatical Reduction & 2 & 12 & 7 & 14 & 6 & 12 & 10 & 15 & 8 & 13 & 99 \\
\hline Phonological Retrieval & & 3 & & & & & 2 & & & & 5 \\
\hline Phonological Substitution & & & & & & & & & & 3 & 3 \\
\hline $\begin{array}{l}\text { Phonological Reduction } \\
\text { (mumbling) }\end{array}$ & & & & & & & 1 & & & & 1 \\
\hline Filled pauses (fillers) & & & 1 & 8 & & & & 1 & 1 & 10 & 21 \\
\hline Unfilled pauses & 23 & 4 & 15 & & 10 & 13 & 13 & 22 & 12 & 4 & 116 \\
\hline Umming and erring & 4 & 32 & 1 & 13 & 20 & 5 & 13 & 8 & 15 & 8 & 119 \\
\hline Lengthening a sound & 13 & 16 & 12 & 11 & 15 & 1 & 32 & 12 & 16 & 8 & 136 \\
\hline Self-repetitions & 20 & 14 & & 2 & 24 & 5 & 15 & 11 & 14 & 17 & 122 \\
\hline Error repair & 4 & 6 & & 29 & 4 & 2 & 5 & 1 & 2 & 1 & 54 \\
\hline Appropriacy repair & 2 & 1 & & 4 & 3 & & & & & 1 & 11 \\
\hline Different repair & 1 & & & 1 & & & 1 & 1 & & & 4 \\
\hline Rephrasing repair & 1 & & & & 1 & & 1 & 1 & & 1 & 5 \\
\hline Own-accuracy checks & & & & 1 & & & & & & & 1 \\
\hline $\begin{array}{l}\text { Total number of CS } \\
\text { per participant }\end{array}$ & 75 & 104 & 38 & 105 & 97 & 42 & 96 & 81 & 74 & 76 & \\
\hline $\begin{array}{l}\text { Total number of different } \\
\text { types of CS per participant }\end{array}$ & 12 & 14 & 7 & 17 & 14 & 10 & 13 & 14 & 9 & 16 & \\
\hline
\end{tabular}


The Advanced Group - session 1

\begin{tabular}{|c|c|c|c|c|c|c|c|c|c|c|c|}
\hline \multirow[b]{2}{*}{ Types of CS } & \multicolumn{10}{|c|}{ Participants } & \multirow{2}{*}{$\begin{array}{r}\text { Frequency } \\
\text { of CS use }\end{array}$} \\
\hline & 7 & 8 & 9 & 10 & 11 & 18 & 19 & 20 & 21 & 30 & \\
\hline Message abandonment & 3 & & & & 1 & 1 & 1 & & 1 & & 7 \\
\hline Message reduction & & 1 & & & & & & & & 1 & 2 \\
\hline Message replacement & 1 & 2 & & & & & & & 1 & & 4 \\
\hline Code-switching & & & 1 & & 3 & & & 5 & & & 9 \\
\hline Approximation & 1 & & & 2 & & 2 & & & & & 5 \\
\hline All-purpose-words & & & & 2 & & & & & 1 & & 3 \\
\hline Complete omission & 3 & & & 3 & 2 & 1 & 2 & 1 & & & 12 \\
\hline Foreignizing & & & & & & & 1 & & & & 1 \\
\hline Grammatical word coinage & & & & & & & & & & 1 & 1 \\
\hline Literal translation & 2 & & & & 1 & & 1 & 1 & & & 5 \\
\hline Circumlocution & & & 1 & 1 & & & 1 & & & & 3 \\
\hline Semantic word coinage & & & & & & & & & & & \\
\hline Restructuring & & 2 & & 2 & 1 & 2 & 4 & 2 & & & 13 \\
\hline Direct appeal & 1 & & & & & & & & & & 1 \\
\hline Indirect Appeal & 1 & & & & 1 & & & & & 1 & 3 \\
\hline Overgeneralization & & 2 & & & & & & 2 & 1 & 1 & 6 \\
\hline Transfer & 4 & 9 & & 2 & 3 & 3 & 12 & 2 & 2 & & 37 \\
\hline Grammatical Reduction & 13 & 13 & 6 & 13 & 19 & 9 & 20 & 20 & 1 & 12 & 126 \\
\hline Phonological Retrieval & 3 & 1 & & 3 & 3 & 1 & 3 & 1 & 4 & 4 & 23 \\
\hline Phonological Substitution & & & & & & & 1 & & & & 1 \\
\hline $\begin{array}{l}\text { Phonological Reduction } \\
\text { (mumbling) }\end{array}$ & & 1 & & & & & & & & 1 & 2 \\
\hline Filled pauses (fillers) & & 1 & & & 1 & 1 & & & & & 3 \\
\hline Unfilled pauses & 19 & 26 & 25 & 15 & 26 & 30 & 39 & 53 & 4 & 37 & 274 \\
\hline Umming and erring & 24 & 12 & & 9 & 25 & 12 & 15 & 9 & 26 & 24 & 156 \\
\hline Lengthening a sound & 40 & 8 & 23 & 24 & 20 & 24 & 28 & 9 & 4 & 40 & 220 \\
\hline Self-repetitions & 15 & 21 & 11 & 14 & 26 & 24 & 32 & 15 & 9 & 13 & 180 \\
\hline Error repair & 4 & 6 & 7 & 3 & 1 & 3 & 4 & & 8 & 2 & 38 \\
\hline Appropriacy repair & 1 & 3 & & 2 & 2 & 1 & 5 & 2 & 3 & 2 & 21 \\
\hline Different repair & 2 & 3 & & 1 & 2 & 2 & & & & 2 & 12 \\
\hline Rephrasing repair & & & 1 & 2 & 1 & & 1 & 1 & 1 & & 7 \\
\hline Own-accuracy checks & 1 & & & & & & & & & & 1 \\
\hline $\begin{array}{l}\text { Total number of CS } \\
\text { per participant }\end{array}$ & 138 & 111 & 75 & 98 & 138 & 116 & 170 & 123 & 66 & 141 & \\
\hline $\begin{array}{l}\text { Total number of different } \\
\text { types of CS per participant }\end{array}$ & 18 & 16 & 8 & 16 & 18 & 15 & 17 & 14 & 14 & 14 & \\
\hline
\end{tabular}


The Advanced Group - session 2

\begin{tabular}{|c|c|c|c|c|c|c|c|c|c|c|c|}
\hline \multirow[b]{2}{*}{ Types of CS } & \multicolumn{10}{|c|}{ Participants } & \multirow{2}{*}{$\begin{array}{r}\text { Frequency } \\
\text { of CS use }\end{array}$} \\
\hline & 7 & 8 & 9 & 10 & 11 & 18 & 19 & 20 & 21 & 30 & \\
\hline Message abandonment & 1 & & & 1 & 2 & & & 1 & 1 & & 6 \\
\hline Message reduction & & 1 & 1 & 1 & 1 & & 2 & & & & 6 \\
\hline \multicolumn{12}{|l|}{ Message replacement } \\
\hline Code-switching & 1 & & & 1 & 2 & 1 & & 2 & & & 7 \\
\hline Approximation & & & 2 & 1 & 1 & 1 & 2 & & & 1 & 8 \\
\hline All-purpose-words & 1 & & & 1 & & & & & & & 2 \\
\hline Complete omission & 1 & 3 & 1 & & 1 & 1 & 3 & & & & 10 \\
\hline Foreignizing & & & & 1 & 1 & & 1 & 1 & & 1 & 5 \\
\hline Grammatical word coinage & & & & 1 & & & & & & & 1 \\
\hline Literal translation & & & & 1 & & & & & & & 1 \\
\hline \multicolumn{12}{|l|}{ Circumlocution } \\
\hline \multicolumn{12}{|l|}{ Semantic word coinage } \\
\hline Restructuring & 1 & 2 & 2 & 1 & 2 & & 1 & & & 1 & 10 \\
\hline \multicolumn{12}{|l|}{ Direct appeal } \\
\hline Indirect Appeal & 1 & & & & & & & & & & 1 \\
\hline Overgeneralization & 4 & & & 1 & 2 & & 4 & & 2 & & 13 \\
\hline Transfer & 1 & 11 & 2 & 4 & 2 & 2 & 3 & 4 & 1 & 1 & 31 \\
\hline Grammatical Reduction & 4 & 23 & 2 & 17 & 25 & 11 & 26 & 15 & 5 & 16 & 144 \\
\hline Phonological Retrieval & 3 & 1 & & 1 & 6 & 1 & 3 & & & 1 & 16 \\
\hline Phonological Substitution & & & 1 & & & & & & & & 1 \\
\hline $\begin{array}{l}\text { Phonological Reduction } \\
\text { (mumbling) }\end{array}$ & & 1 & & & & & & 1 & 2 & 1 & 5 \\
\hline Filled pauses (fillers) & & 1 & & 1 & & 2 & & & 1 & & 5 \\
\hline Unfilled pauses & 28 & 7 & 9 & 19 & 26 & 9 & 23 & 43 & 33 & 16 & 213 \\
\hline Umming and erring & 23 & 25 & 3 & 10 & 27 & 10 & 35 & 10 & 3 & 21 & 167 \\
\hline Lengthening a sound & 9 & 3 & 18 & 20 & 40 & 3 & 37 & 5 & 2 & 51 & 188 \\
\hline Self-repetitions & 18 & 43 & 20 & 36 & 35 & 25 & 23 & 11 & 8 & 24 & 243 \\
\hline Error repair & 1 & 1 & 3 & 2 & 5 & 2 & 6 & 2 & & 3 & 25 \\
\hline Appropriacy repair & & 6 & 4 & 3 & 1 & 2 & 3 & 1 & 2 & 2 & 24 \\
\hline Different repair & & 2 & 1 & 1 & 2 & & 3 & 2 & & 5 & 16 \\
\hline Rephrasing repair & 2 & 4 & 2 & 1 & 1 & 1 & 1 & & & 2 & 14 \\
\hline \multicolumn{12}{|l|}{ Own-accuracy checks } \\
\hline $\begin{array}{l}\text { Total number of CS per } \\
\text { participant }\end{array}$ & 99 & 134 & 71 & 125 & 182 & 71 & 176 & 98 & 60 & 146 & \\
\hline $\begin{array}{l}\text { Total number of different } \\
\text { types of CS per participant }\end{array}$ & 16 & 16 & 15 & 22 & 19 & 14 & 17 & 13 & 11 & 15 & \\
\hline
\end{tabular}


The Advanced Group - session 3

\begin{tabular}{|c|c|c|c|c|c|c|c|c|c|c|c|}
\hline \multirow[b]{2}{*}{ Types of CS } & \multicolumn{10}{|c|}{ Participants } & \multirow{2}{*}{$\begin{array}{r}\text { Frequency } \\
\text { of CS use }\end{array}$} \\
\hline & 7 & 8 & 9 & 10 & 11 & 18 & 19 & 20 & 21 & 30 & \\
\hline Message abandonment & & & & & & & 1 & & 1 & & 2 \\
\hline Message reduction & & 1 & & & & & & & & & 1 \\
\hline Message replacement & & & & & & & & & & & \\
\hline Code-switching & & 3 & & 2 & & 1 & 4 & 1 & 1 & & 12 \\
\hline Approximation & 4 & & 1 & 1 & 5 & 1 & 4 & 1 & 1 & 2 & 20 \\
\hline All-purpose-words & & & & & & & 1 & & 1 & & 2 \\
\hline Complete omission & & 2 & & & & 1 & & & 1 & & 4 \\
\hline Foreignizing & & & & 1 & & & & 1 & & & 2 \\
\hline Grammatical word coinage & & & & & & & & & 1 & & 1 \\
\hline Literal translation & 1 & 1 & & 1 & & & 1 & 2 & & & 6 \\
\hline Circumlocution & & & & 2 & & 1 & & & & & 3 \\
\hline Semantic word coinage & & & & & & & & & & & \\
\hline Restructuring & 1 & 1 & & & & & & & & 2 & 4 \\
\hline Direct appeal & & & 1 & & & & & & 1 & & 2 \\
\hline Indirect Appeal & 1 & 1 & 1 & & 2 & 1 & & & & & 6 \\
\hline Overgeneralization & 1 & 2 & & & & & 3 & & & 2 & 8 \\
\hline Transfer & & 1 & 1 & 3 & & 1 & 2 & 5 & & 1 & 14 \\
\hline Grammatical Reduction & 16 & 15 & 7 & 18 & 12 & 11 & 19 & 13 & 6 & 13 & 130 \\
\hline Phonological Retrieval & & 4 & 2 & & 2 & & 1 & 1 & 1 & 1 & 12 \\
\hline Phonological Substitution & 1 & & & & & & & & & 1 & 2 \\
\hline $\begin{array}{l}\text { Phonological Reduction } \\
\text { (mumbling) }\end{array}$ & 2 & 2 & & 2 & & & & & & & 6 \\
\hline Filled pauses (fillers) & & 1 & & 2 & 1 & & & 1 & & & 5 \\
\hline Unfilled pauses & 16 & 12 & 17 & 13 & 26 & 14 & 23 & 26 & 15 & 13 & 175 \\
\hline Umming and erring & 14 & 10 & 1 & & 10 & 6 & 4 & 2 & & 3 & 50 \\
\hline Lengthening a sound & 29 & 19 & 21 & 27 & 23 & 13 & 12 & & 11 & 33 & 188 \\
\hline Self-repetitions & 14 & 19 & 16 & 10 & 13 & 14 & 31 & 5 & 2 & 6 & 130 \\
\hline Error repair & 1 & 3 & & 3 & 2 & 2 & 3 & 3 & 3 & 1 & 21 \\
\hline Appropriacy repair & 3 & 2 & 2 & 3 & 3 & 2 & & 1 & 1 & 4 & 21 \\
\hline Different repair & & & & & & & 2 & & & 1 & 3 \\
\hline Rephrasing repair & 1 & 1 & 1 & & & 1 & 2 & & & & 6 \\
\hline Own-accuracy checks & & & & & 2 & & & & & & 2 \\
\hline $\begin{array}{l}\text { Total number of CS per } \\
\text { participant }\end{array}$ & 105 & 100 & 71 & 88 & 101 & 69 & 113 & 62 & 46 & 83 & \\
\hline $\begin{array}{l}\text { Total number of different } \\
\text { types of CS per participant }\end{array}$ & 15 & 19 & 12 & 14 & 12 & 14 & 16 & 13 & 14 & 14 & \\
\hline
\end{tabular}


Appendix B - Individual Speech Rate Scores

Session 1

Pre-Intermediate

\begin{tabular}{cccccc}
\hline Participant & min & sec & cent & Words & Speech Rate \\
\hline 1 & 1 & 49 & 15 & 93 & 51,12 \\
2 & 5 & 0 & 0 & 267 & 53,40 \\
5 & 4 & 45 & 93 & 218 & 45,75 \\
6 & 5 & 0 & 0 & 342 & 68,40 \\
12 & 1 & 52 & 0 & 129 & 69,11 \\
13 & 2 & 8 & 20 & 84 & 39,31 \\
14 & 4 & 57 & 0 & 209 & 42,22 \\
16 & 3 & 10 & 55 & 202 & 63,61 \\
17 & 4 & 55 & 67 & 380 & 77,11 \\
33 & 3 & 0 & 0 & 296 & 98,67 \\
\hline
\end{tabular}

Intermediate

\begin{tabular}{cccccc}
\hline Participant & min & sec & cent & Words & Speech Rate \\
\hline 22 & 4 & 56 & 74 & 343 & 69,35 \\
23 & 3 & 41 & 0 & 246 & 66,79 \\
24 & 4 & 55 & 0 & 395 & 80,34 \\
25 & 5 & 0 & 0 & 525 & 105,00 \\
26 & 3 & 44 & 0 & 500 & 133,93 \\
27 & 4 & 52 & 0 & 494 & 101,51 \\
28 & 5 & 0 & 0 & 424 & 84,80 \\
29 & 4 & 49 & 0 & 421 & 87,40 \\
31 & 4 & 52 & 0 & 329 & 67,60 \\
32 & 4 & 44 & 0 & 607 & 128,24 \\
\hline
\end{tabular}

Advanced

\begin{tabular}{cccccc}
\hline Participant & min & sec & cent & Words & Speech Rate \\
\hline 7 & 4 & 10 & 0 & 450 & 108,00 \\
8 & 4 & 19 & 0 & 465 & 107,72 \\
9 & 3 & 53 & 0 & 417 & 107,38 \\
10 & 3 & 15 & 0 & 291 & 89,54 \\
11 & 5 & 0 & 0 & 525 & 105,00 \\
18 & 4 & 58 & 0 & 562 & 113,15 \\
19 & 5 & 0 & 0 & 532 & 106,40 \\
20 & 4 & 53 & 0 & 354 & 72,49 \\
21 & 3 & 15 & 63 & 321 & 98,45 \\
30 & 5 & 0 & 0 & 404 & 80,80 \\
\hline
\end{tabular}


Session 2

Pre-Intermediate

\begin{tabular}{cccccc}
\hline Participant & min & sec & cent & Words & Speech Rate \\
\hline 1 & 1 & 25 & 0 & 128 & 90,35 \\
2 & 3 & 59 & 30 & 314 & 78,73 \\
5 & 4 & 58 & 0 & 193 & 38,86 \\
6 & 2 & 5 & 90 & 221 & 105,32 \\
12 & 3 & 23 & 64 & 206 & 60,70 \\
13 & 3 & 49 & 0 & 226 & 59,21 \\
14 & 3 & 33 & 0 & 174 & 49,01 \\
16 & 4 & 38 & 0 & 202 & 43,60 \\
17 & 2 & 38 & 0 & 179 & 67,97 \\
33 & 2 & 34 & 0 & 278 & 108,31 \\
\hline
\end{tabular}

Intermediate

\begin{tabular}{cccccc}
\hline Participant & min & sec & cent & Words & Speech Rate \\
\hline 22 & 4 & 21 & 30 & 351 & 80,60 \\
23 & 4 & 42 & 0 & 307 & 65,32 \\
24 & 2 & 56 & 70 & 241 & 81,83 \\
25 & 2 & 39 & 93 & 255 & 95,67 \\
26 & 5 & 0 & 0 & 530 & 106,00 \\
27 & 4 & 10 & 0 & 530 & 127,20 \\
28 & 5 & 0 & 0 & 401 & 80,20 \\
29 & 3 & 1 & 40 & 265 & 87,65 \\
31 & 2 & 37 & 65 & 213 & 81,07 \\
32 & 5 & 0 & 0 & 506 & 101,20 \\
\hline
\end{tabular}

Advanced

\begin{tabular}{cccccc}
\hline Participant & min & sec & cent & Words & Speech Rate \\
\hline 7 & 4 & 27 & 0 & 322 & 72,36 \\
8 & 4 & 56 & 79 & 623 & 125,95 \\
9 & 3 & 21 & 0 & 408 & 121,79 \\
10 & 5 & 0 & 0 & 513 & 102,60 \\
11 & 4 & 47 & 41 & 495 & 103,34 \\
18 & 3 & 33 & 61 & 352 & 98,87 \\
19 & 5 & 0 & 0 & 565 & 113,00 \\
20 & 4 & 38 & 38 & 300 & 64,66 \\
21 & 4 & 43 & 0 & 395 & 83,75 \\
30 & 4 & 36 & 0 & 482 & 104,78 \\
\hline
\end{tabular}




\section{Session 3}

Pre-Intermediate

\begin{tabular}{cccccc}
\hline Participant & min & sec & cent & Words & Speech Rate \\
\hline 1 & 1 & 24 & 35 & 105 & 74,69 \\
2 & 2 & 45 & 37 & 194 & 70,39 \\
5 & 3 & 25 & 54 & 168 & 49,04 \\
6 & 3 & 34 & 62 & 240 & 67,10 \\
12 & 4 & 11 & 30 & 208 & 49,66 \\
13 & 2 & 7 & 38 & 129 & 60,76 \\
14 & 3 & 14 & 0 & 133 & 41,13 \\
16 & 4 & 0 & 0 & 167 & 41,75 \\
17 & 4 & 56 & 50 & 170 & 34,40 \\
33 & 1 & 57 & 60 & 166 & 84,69 \\
\hline
\end{tabular}

Intermediate

\begin{tabular}{cccccc}
\hline Participant & min & sec & cent & Words & Speech Rate \\
\hline 22 & 3 & 16 & 76 & 218 & 66,48 \\
23 & 4 & 29 & 14 & 238 & 53,06 \\
24 & 2 & 19 & 62 & 173 & 74,34 \\
25 & 3 & 11 & 59 & 285 & 89,25 \\
26 & 3 & 47 & 81 & 350 & 92,18 \\
27 & 1 & 24 & 90 & 144 & 101,77 \\
28 & 3 & 34 & 60 & 257 & 71,85 \\
29 & 2 & 56 & 94 & 201 & 68,16 \\
31 & 1 & 55 & 40 & 114 & 59,27 \\
32 & 2 & 9 & 15 & 241 & 111,96 \\
\hline
\end{tabular}

Advanced

\begin{tabular}{cccccc}
\hline Participant & min & Sec & cent & Words & Speech Rate \\
\hline 7 & 2 & 56 & 91 & 314 & 106,49 \\
8 & 3 & 13 & 7 & 367 & 114,05 \\
9 & 3 & 16 & 0 & 333 & 101,94 \\
10 & 3 & 15 & 0 & 299 & 92,00 \\
11 & 4 & 34 & 67 & 275 & 60,07 \\
18 & 3 & 31 & 50 & 322 & 91,35 \\
19 & 3 & 4 & 50 & 353 & 114,80 \\
20 & 2 & 37 & 0 & 188 & 71,85 \\
21 & 2 & 29 & 0 & 255 & 102,68 \\
30 & 2 & 20 & 0 & 241 & 103,29 \\
\hline
\end{tabular}

